\title{
Analisis Komparasi Kualitas Laba Sebelum dan Sesudah Konvergensi Penuh IFRS di Indonesia
}

Pradisa Shinta ${ }^{1}$, Suyanto ${ }^{2}$

${ }^{1}$ Universitas Pancasila, Jl. Srengseng Sawah, Jagakarsa, Jakarta Selatan 12640

${ }^{2}$ Sekolah Tinggi Ilmu Ekonomi IPWIJA, Jl. Letda Natsir No.7 Nagrak, Gn. Putri Cibubur - Bogor

I N F O A R T I K E L

JEL Classification:

M41

Keywords:

IFRS, earnings quality,

accrual quality,

earnings peristence,

value relevance

\section{$A B S T R A C T$}

Study was conducted to determine differences in the quality of earnings before and after the full IFRS convergence in Indonesia in terms of accrual accounting is the quality and persistence of earnings while from the market is the relevance value. Sample selection is done using purposive sampling method with the number of sampale total of 77 companies listed on the Stock Exchange during the period 2010 - 2015. The analysis technique used is linear regression which is then tested different. The results showed that the only variable in terms of higher quality accounting in the period after the full IFRS convergence in Indonesia with significant differences. While variable in terms of quality on the market is not over after a period of convergence of IFRS with no significant differences.

\section{A B S T R A K}

Penelitian ini dilakukan untuk mengetahui perbedaan kualitas laba sebelum dan sesudah konvergensi penuh IFRS di Indonesia dari sisi akuntansi yaitu kualitas akrual dan persistensi laba sedangkan dari sisi pasar yaitu relevansi nilai. Pemilihan sampel dilakukan menggunakan metode purpose sampling dengan jumlah sample sebanyak 77 perusahaan manufaktur yang terdaftar di BEI selama periode 2010 - 2015. Teknik analisis yang digunakan adalah regresi linier yang kemudian diuji beda. Dari hasil penelitian menunjukkan bahwa hanya variabel dari sisi akutansi yang lebih berkualitas pada periode sesudah konvergensi penuh IFRS di Indonesia dengan perbedaan signifikan. Sedangkan variabel dari sisi pasar tidak menjadi lebih berkualitas pada periode sesudah konvergensi IFRS dengan tidak adanya perbedaan yang signifikan.

\section{Pendahuluan}

Laporan keuangan yang disusun manajemen mengandung informasi kinerja perusahaan yang berfungsi sebagai pengambilan keputusan. Agar tidak terjadi kesalahan dalam pengambilan keputusan maka suatu laporan keuangan harus mengandung informasi yang berkualitas. Kualitas dari laporan keuangan itu sendiri dipengaruhi oleh standar akuntansi yang digunakan. Dibutuhkan sebuah aturan atau standar baku yang dapat meningkatkan kualitas pengungkapan dan penyajian informasi pada setiap laporan keuangan sehingga dapat menghasilan kualitas laba yang tinggi, standar akuntansi secara umum diterima sebagai aturan baku yang didukung oleh sanksi sanksi untuk setiap ketidakpatuhan (Belkaoui, 2006, dalam

*Email Korespondensi: 'pradisa.shinta@gmail.com, 2suyantowalidi@gmail.com 
Ayub, 2013).

Seiring berkembangannya waktu perlu adanya standar akuntansi yang dapat menciptakan keselarasan dalam pelaporan keuangan sebab pada era globalisasi saat ini banyak perusahaan yang melakukan transaksi bisnis lintas negara. Untuk mengatasinya IASB mengeluarkan standar yangdisebut International FinancialReporting Standard (IFRS) yang merupakan standar akuntansi keuangan dalam menjembatani perbedaan yang ada dalam pelaporan keuangan di berbagai negara (Prastika, dkk, 2013).

Tujuan IFRS itu sendiri memastikan laporan keuangan mengandung informasi berkualitas tinggi yaitu laporan keuangan yang memenuhi beberapa kriteria sebagai berikut : (1) Menghasilkan transparansi bagi para pengguna dan dapat dibandingkan sepanjang periode yang disajikan, (2) Menyediakan titik awal yang memadai untuk akuntansi yang berdasarkan pada IFRS, (3) Dapat dihasilkan dengan biaya yang tidak melebihi manfaat untuk para penggunanya (Gamayuni, 2009).Daritujuanyang dikemukakan, IFRS ini diharapkan dapat meningkatkan kualitas akuntansi laporan keuangan yang disajikan.

Tahap Transisi Indonesia dari PSAK ke IFRS di mulai tahun 2008 sampai tahun 2010 yang kemudian melakukan pesiapan infrastruktur di tahun 2011 dan pada tahun 2012 sudah melakukan adopsi penuh IFRS bagi Perusahaan yang memiliki akuntanbilitas publik (Purba, 2009). Ciri utama IFRS itu sendiri yaitu principles based adalah adanya pelaporan menggunakan fair value dimana perusahaan akan melaporkan aset dan kewajibannya sejumlah nilai wajarnya ketika aset atau kewajiban itu di pasar aktif. Standar yang berisi prinsiples based hanya mengatur hal - hal prinsip bukan aturan detail. Konsekuensinya dibutuhkan profesional judgment dalam menerapkan standar. Untuk dapat memiliki profesional judgment seorang akuntan harus memiliki pengetahuan, skill dan etika karena jika tidak memiliki ketiganya hal tersebut maka profesional judgmentyang diambil tidak tepat (Martani, 2011).

Pada PSAK sebelum periode pengadopsian IFRS sebenarnya telah menggunakan dasar nilai wajar, namun nilai wajar diterapkan pada pencatatan awal dan penilaian sesudah pencatatan awal untuk beberapa aset yang memiliki nilai wajar yang dapat diandalkan. IFRS mengharuskan pemgungkapan yang lebih luas agar pemakai laporan keuangan mendapat informasi yang lebih banyak sehingga dapat mempertimbangkan informasi tersebut untuk pengambilan keputusan (Martani, 2011). Selain perbedaan diatas, infrastruktur yang kurang siap dan kondisi peraturan perundangan yang belum tentu sinkron dengan IFRS dikhawatirkan akan mempengaruhi kualitas akuntansi yang seharusnya mengalami peningkatan dalam laporan keuangan menjadi tidak berdampak pada laporan keuangan.

Memang masih terjadi perdebatan apakah IFRS dapat meningkatkan kualitas informasi akuntansi (Barth dkk., 2008; Daske dkk., 2008; Karampinis dan Hevas, 2011; Alali dan Foote, 2012).Sebagai contoh, hasil penelitian Bartov dkk. (2005), Liu dan Liu (2007), Barth dkk. (2008), dan Alali dan Foote (2012) menunjukkan informasi akuntansi yang telah disusun berdasar IFRS/IAS lebih berkualitas dibandingkan informasi akuntansi yang disusun berdasar standar akuntansi sebelumnya. Sebaliknya, hasil penelitian Van der Meulen (2007), Hung dan Subramayam (2007), serta Karampinis dan Hevas (2011) menunjukkan bukti empiris yang bertentangan. Mereka menunjukkan tidak ada peningkatan signifikan dalam kualitas informasi akuntansi setelah adopsi IFRS (Nur dan Dwi, 2012). Beragam hasil penelitian terdahulu maka penulis tertarik melakukan penelitian terhadap variabel yang digunakan untuk memprediksi kualitas laba, apakah terdapat perbedaan signifikan antara kualitas laba sebelum dengan sesudah konvergensi penuh IFRS di Indonesia.

\section{Telaah Teori dan Pengembangan Hipotesis}

\section{Teori Sinyal}

Laporan keuangan mengandung informasi penting mengenai suatu perusahaan. Menurut Wolk, et al. (2000) teori sinyal menjelaskan alasan perusahaan menyajikan informasi untukpasar modal, juga menunjukkan adanya 
asimetri informasi antara manajemenperusahaan dan pihak-pihak yang berkepentingan dengan informasi tersebut. Teori signal juga dapat membantu pihak perusahaan (agent), pemilik (prinsipal), dan pihak luar perusahaan mengurangi asimetri informasi dengan menghasilkan kualitas atau integritas informasi laporan keuangan. Untuk memastikan pihak-pihak yang berkepentingan meyakini keandalan informasi keuangan yang disampaikan pihak perusahaan (agent), perlu mendapatkan opini dari pihak lain yang bebas memberikan pendapat tentang laporan keuangan (Jama'an,2008).

Dari pendapat yang ada teori sinyal memfokuskan pada kandungan informasi dari laporan keuangan yang dapat dimanfaatkan pihak eksternal untuk pengambilan keputusan investasi. Suatu laporan keuangan yang berkualitas akan sangat bermanfaat bagi pengguna laporan keuangan dalam pengambilan keputusan dalam suatu pasar modal guna analisis keputusan invetasinya. Salah satu yang biasanya menjadi fokus pengguna laporan keuangan adalah informasi laba yang mencerminkan kinerja perusahaan.Berkualitas atau tidaknya informasi laba ini juga tidak lepas dari penggunaan standar yang mengatur sebuah laporan keuangan.

\section{International Financial Reporting Standard}

Aspek akuntansi merupakan aspek tidak lepas dari pengaruh adanya era globalisasi yang bekembang saat ini. Transaksi lintas batas suatu negara mejadi salah satu alasan untuk menyeragamkan informasi keuangan. Dalam penyeragaram suatu laporan keuangan butuh standar akutansi tentang pengakuan, penyajian dan pengungkapan yang berkualitas guna mempermudah memahami informasi yang tersaji agar meminimalisir kesalahan dalam pengambilan keputusan investasi.

International Financial Reporting Standards(IFRS)merupakanstandarakuntansiatas penyusunan laporan keuangan yang diberlakukan oleh Interational Accounting Standards (IAS). IFRS memiliki tiga ciri utama yaitu principles based, lebih banyak menggunakan nilai wajar sebagai dasar penilaian dan pengungkapan yang lebih banyak. Standar yang bersifat principles based hanya mengaturhal-hal prinsip bukan aturan detail. Konsekuensinya diperlukan professional judgment dalam menerapkan standar.Untuk dapat memiliki professional judgment seorang akuntan harus memiliki pengetahuan, skill dan etika karena jika tidak memiliki ketiga hal tersebut maka professional judgment yang diambil tidak tepat. Dalam standar yang lama sebenarnya telah menggunakan dasar nilai wajar, namun nilai wajar diterapkan pada pencatatan awal dan penilaian sesudah pencatatan awal untuk beberapa aset yang memiliki nilai wajar yang dapat diandalkan (aset yang memiliki kuotasi pasar aktif seperti saham). Dalam IFRS penggunaan nilai wajar diperluas bahkan untuk aset biologi (contoh tanaman atau hewan ternak), aset tetap, properti investasi dan aset tidak berwujud sebagai pilihan metode selain metode biaya. IFRS mengharuskan pengungkapan yang lebih luas agar pemakai laporan keuangan mendapatkan informasi yang lebih banyak sehingga dapat mempertimbangkan informasi tersebut untuk pengambilan keputusan (Martani, 2011).

\section{Kualitas Laba}

Francis et al (2004) membagi kriteria laba menjadi dua atribut yaitu accunting based yang menggunakan laba sebagai landasan dasarnya dengan kriteria kualitas akrual, persistensi, prediktabilias dan smoothness sedangkan untuk market based menggunakan harga saham sebagai landasan dasarnya dengan kriteria relevansi nilai, ketepatan waktu dan konservatisme. Pada penelitian ini penulis focus pada kualitas akrual dan persisitensi laba dari sisi akuntansi dan relevansi nilai dari sisi pasar guna melihat kualitas laba.

Kualitas akrual menentukan sejauh mana akrual (dan laba pada umumnya) memetakan ke arus kas operasi(Francis et al, 2004).Dechow dan Dichev (2002) baru-baru ini telah mengembangkan proxy untuk mengukur kualitas laba, mereka berpendapat bahwa akrual dimaksudkan untuk menyesuaikan pengakuan arus kas dari waktu ke waktu.Pengukuran akrual dengan kualitas akrual merupakan estimasi dari 
arus kas operasi periode sebelumnya, saat ini dan periode yang akan datang pada perubahan modal kerja.

Persistensi laba akuntansi adalah revisi dalam laba akuntansi yang diharapkan dimasa depan (expedted future earnings) yang diimplikasi oleh laba tahun berjalan (Djamaluddin, 2008:55). Persistensi laba dalam pengukuran kualitas laba berarti bahwa laba dikatakan berkualitas apabila laba terus terulang kembali dari waktu ke waktu atau dengan kata lain laba yang berkualitas adalah laba yang berkesinabungan dan permanen.

Relevansi nilai didefinisikan sebagai kemampuan angka - angka akuntansi untuk merangkum informasi yang mendasari harga saham, sehingga relevansi nilai diindikasikna dengan sebuah statistikal antara informasi keuangan dan harga atau return saham.Barth dkk (2008) mengemukakan bahwa kualitas informasi akutansi yang tinggi diindikasikan dengan adanya hubungan yang kuat antara harga atau return saham dan laba serta nilai buku ekuitas karena kedua informasiakuntansi tersebut mencerminkan kondisi ekonomik perusahaan.

\section{Kualitas laba dari sisi kualitas akrual sebelum dan sesudah konvergensi IFRS}

Kualitas akrual menentukan sejauh mana akrual (dan laba pada umumnya) memetakan ke arus kas operasi(Francis et al, 2004).Barth (2006) dalam penelitiannya mengemukakan bahwa perusahan yang menerapkan IFRS terbukti dapat mengurangi praktik manajemen laba dengan perubahan arus kas yang signifikan. Kualitas akrual menjadi dasar untuk melakukan praktik manajemen laba (Dechow dan Divechev, 2002) sehingga diasumsikan turunnya manajemen laba dengan konvergensi IFRS ini dengan meningkatkan kualitas akrual. Berdasarkan pada uraian diatas maka dapat dirumuskan hipotesis sebagai berikut :

$\mathrm{H}_{1 \mathrm{a}}$ : Terdapat perbedaan signifikan pada kualitas akrual sebelum dan sesudah konvergensi IFRS

\section{Kualitas laba dari sisi persistensi laba sebelum dan sesudah konvergensi IFRS}

Laba yang semakin persisten menunjukkan laba semakin informatif, sebaliknya jika laba kurang persisten, maka laba menjadi kurang informatif (Tucker dan Zarowin, 2006). Kurniawati (2012) mengemukakan adanya perubahan yang terjadi akibat pengadopsian IFRS dengan karakteristik utama yaitu penekanan pada fair value akan mempengaruhi metode akuntansi yang berdampak pada laba perusahaan. Adanya perubahan akan berdampak pada peningkatan atau penurunan laba perusahaan yang tentunya akan menimbulkan sejauh mana persistensi laba sesudah pengadopsian IFRS. Berdasarkan pada uraian diatas maka dapat dirumuskan hipotesis sebagai berikut :

$\mathrm{H}_{1 b}$ : Terdapat perbedaan signifikan pada persistensi laba sebelum dan sesudah konvergensi IFRS

\section{Kualitas laba dari sisi relevansi nilai sebelum dan sesudah konvergensi IFRS}

Tingginya hubungan antara laba dan return pasar menunjukkan semakin berkualitas informasi yang ditunjukkan oleh lapora laba rugi tersebut (Ball dan Brown, 1986). Menurut Claudya (2014) adanya pengadopsian IFRS dalam laporan keuangan berdampak semakin meningkatnya relevansi nilai karena principles based yang menjadi standars dari IFRS serta pengukuran dengan fair value diasumsikan lebih dapat menggambarkan posisi dan kinerja ekonomik perusahaan, sehingga laporan keuangan dapat dikatakan lebih relevan. Berdasarkan pada uraian diatas maka dapat dirumuskan hipotesis sebagai berikut :

$\mathrm{H}_{2}$ : Terdapat perbedaan signifikan pada relevansi nilai sebelum dan sesudah konvergensi IFRS

\section{Metode}

Pemilihan sampel menggunakan metode purposive sampling yaitu pemilihan sampel secara acak pada seluruh perusahaan manufaktur yang terdaftar di Bursa Efek Indonesia (BEI), periode yang diambil sebelum konvergensi IFRS adalah tahun 2010 dan 2011 sedangkan periode yang 
diambil sesudah konvergensi IFRS adalah tahun 2014 dan tahun 2015 dengan kriteria - kriteria: 1)Perusahaan manufaktur yang terdaftar dalam Bursa Efek Indonesia selama tahun pengamatan; 2) Perusahaan konsisten mempublikasikan data laporan keuangan selama tahun pengamatan yang telah diaudit; 3) Laporan keuangan yang diterbitkan menggunakan mata uang Rupiah selama tahun pengamatan; 4) Tersedia dan mengandung informasi yang dibutuhkan selama tahun pengamatan. Definisi operasional dan pengukuran variable sebagaimana tabel 1 .

Kualitas laba menurut Francis et al (2004) yang digunakan dalam penelitian ini adalah kualitas akrual, pesistensi laba dari accounting based dan relevansi nilai dari market based. Dari ketiga atribut laba ini setiap atribut akan diregresikan terpisah antara periode sebelum konvergensi IFRS dan sesudah kovergensi IFRS dengan analisis regresi linier untuk mengevaluasi hubungan variabel dependen dan variabel inde- pendennya. Setelah mendapatkan hasil regresi atas kualitas akrual, persistensi laba, relevansi nilai pada periode sebelum konvergensi dan setelah konvergensi kemudian diuji dengan menggunakan uji beda, jika data berdistribusi normal maka menggunakan Paried Sample $T$ - Test sedangkan data tidak berdistribusi normal maka menggunakan Uji Wilcoxon untuk mengetahui ada tidaknya perbedaan ketiga atribut kualitas laba sebelum dan sesudah konvergensi penuh IFRS.

\section{Analisis Hasil dan Pembahasan}

Berdasarkan kriteria purposive sampling maka diperoleh jumlah sample penelitian yang sesuai dengan kriteria sebanyak 77 perusahaan manufaktur. Data diperoleh dari laporan keuangan publikasi tahunan selama 4 tahun yaitu 2010 dan 2011 untuk tahun sebelum IFRS dengan 2014 dan 2015 untuk tahun sesudah IFRS. (tabel.2)

Tabel 1. Ringkasan Definisi Operasional dan Indikator Variabel

\begin{tabular}{|c|c|c|c|c|c|}
\hline No & Variabel & Definisi & Pengukuran & Skala & Acuan \\
\hline 1 & Kualitas Akual & $\begin{array}{l}\text { Kualitas akrual menentukan } \\
\text { sejauh mana akrual (dan } \\
\text { laba pada umumnya) } \\
\text { memetakan ke arus kas } \\
\text { operasi. Semakin rendah } \\
\text { standar deviasi maka } \\
\text { semakin tinggi kualitas } \\
\text { akrualnya dan sebaliknya. }\end{array}$ & $\begin{array}{l}\text { Total akrual }= \\
\text { Arus kas operasi } \\
\text { Total rata - rata } \\
\text { aset dan }_{t}^{-1}\end{array}$ & Rasio & $\begin{array}{l}\text { Francis et } \\
\text { al (2004) }\end{array}$ \\
\hline 2 & Persistensi & $\begin{array}{l}\text { Persistensi laba akuntansi } \\
\text { adalah revisi dalam laba } \\
\text { akuntansi yang diharapkan } \\
\text { dimasa depan (expedted } \\
\text { future earnings) yang } \\
\text { diimplikasi oleh laba tahun } \\
\text { berjalan. Semakin besar } \\
\text { nilai } R^{2} \text { semakin berkualitas } \\
\text { laba yang dihasilkan. }\end{array}$ & $\begin{array}{l}\text { Earning before } \\
\text { extraordinary } \\
\text { item ditahun }{ }_{\mathrm{t}}= \\
\text { Earning before } \\
\text { extraordinary } \\
\text { item ditahun }_{\mathrm{t}}^{-1}\end{array}$ & Rasio & $\begin{array}{l}\text { Francis et } \\
\text { al (2004) }\end{array}$ \\
\hline 3 & $\begin{array}{l}\text { Relevansi } \\
\text { Nilai }\end{array}$ & $\begin{array}{l}\text { Relevansi nilaididefinisikan } \\
\text { sebagai kemampuan angka } \\
\text { - angka akuntansi untuk } \\
\text { merangkum informasi yang } \\
\text { mendasari harga saham. }\end{array}$ & $\begin{array}{l}\text { Return saham } \\
\text { selama } 15 \text { bulan }_{t} \\
=\text { EPS tahun } \\
\text { bejalan dibagi } \\
\text { dengan harga } \\
\text { pasar saham } \\
t_{t}^{-1}\end{array}$ & Rasio & $\begin{array}{l}\text { Francis et } \\
\text { al (2004) }\end{array}$ \\
\hline
\end{tabular}

Sumber: Jurnal Penelitian Sebelumnya 
Tabel 2. Statistik Deskriptif Kualital Akrual

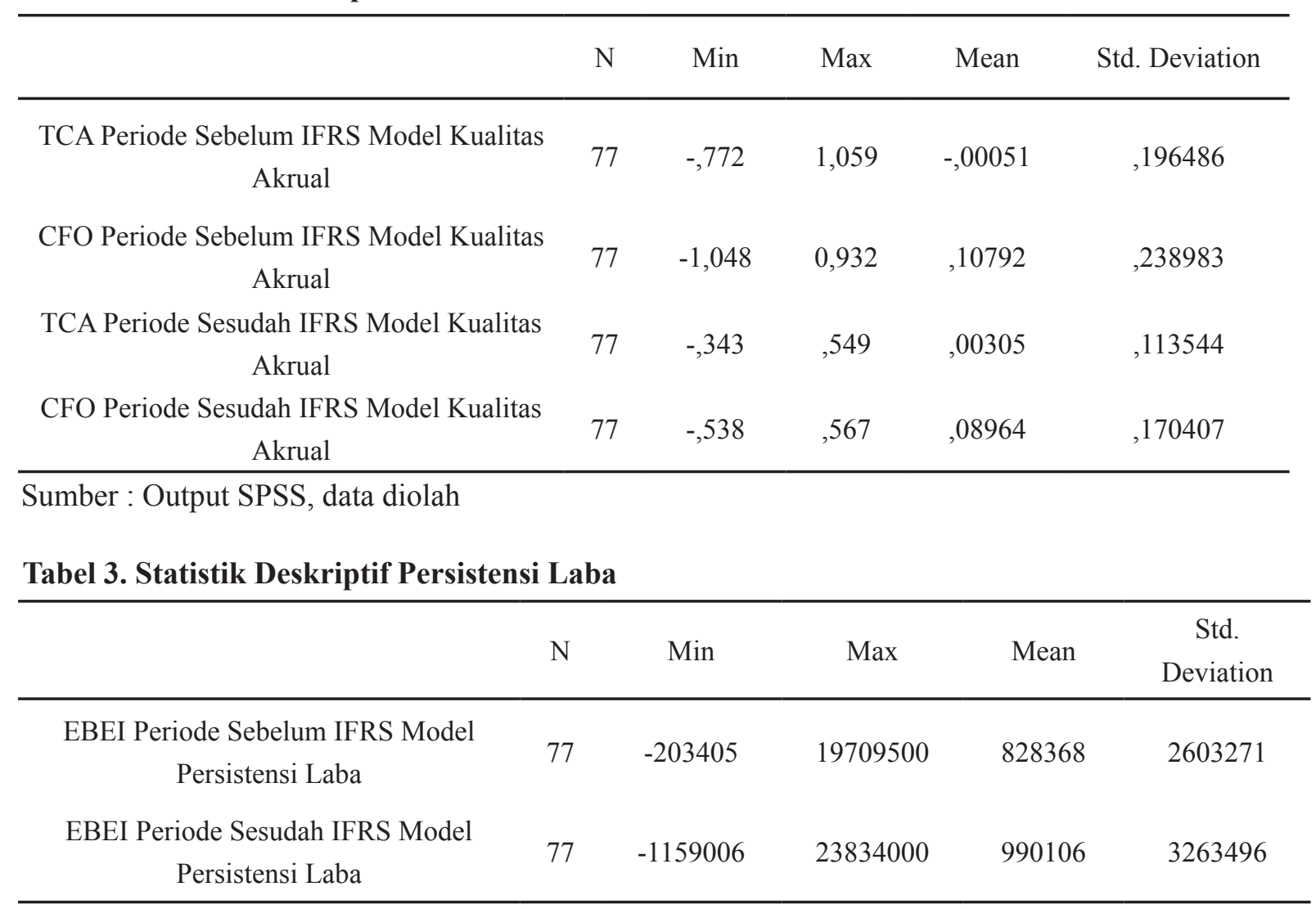

Sumber : Output SPSS, data diolah

Tabel 4. Statistik Deskriptif Relevansi Nilai

\begin{tabular}{lcccc}
\hline & Min & Max & Mean & Std. Deviation \\
\hline $\begin{array}{l}\text { RET Periode Sebelum IFRS Model } \\
\text { Relevansi Nilai }\end{array}$ &,- 019 &, 810 &, 02451 &, 097464 \\
$\begin{array}{l}\text { EARN Periode Sebelum IFRS Model } \\
\text { Relevansi Nilai }\end{array}$ &,- 945 & 3,626 &, 21995 &, 541908 \\
$\begin{array}{l}\text { RET Periode Sesudah IFRS Model } \\
\text { Relevansi Nilai }\end{array}$ &,- 009 &, 043 &, 00069 &, 006306 \\
$\begin{array}{l}\text { EARN Periode Sesudah IFRS Model } \\
\text { Relevansi Nilai }\end{array}$ &,- 659 &, 304 & 0,1990 & 0,143802 \\
\hline
\end{tabular}

Sumber : Output SPSS, data diolah

Berdasarkan tabel 2 model kualitas akrual menggunakan variabel Total Akrual (TCA) yang diperoleh dari selisih aktiva lancar dikurangi selisih kewajiban lancar dikurangi selisih kas ditambah dengan selisih hutang kewajiban lancar yang kemudian dibagi dengan rata - rata aset dan variabel Arus Kas Operasi (CFO) yang diperoleh dari laba bersih sebelum pos luar biasa dikurangi total akrual.
Berdasarkan tabel 3 model persistensi laba menggunakan variabel Earning Before Extraordinary Item (EBEI). Terlihat rata - rata Earning Before Extraordinary Item pada periode sebelum pengadopsian IFRS adalah sebesar $828.368,31$ dengan standar deviasi sebesar 2.603.271,130.

Berdasarkan tabel.4 diatas model relevansi nilai dijelaskan oleh return saham 
selama 15 bulan (RET) dan EPS tahun berjalan dibagi dengan harga pasar saham pada tahun $\mathrm{t}-1$ (EARN). Terlihat pada tabel untuk rata - rata total return saham pada periode sebelum pengadopsian IFRS adalah sebesar 0,02451 dengan standar deviasi sebesar 0,097464.

Uji regresi dilakukan untuk masing masing model kualitas akrual, persistensi laba, relevansi nilai setiap perusahaan pada periode sebelum dan periode sesudah IFRS. Hasil dari kualitas akrual adalah nilai $R$-squared dari model $\mathbf{T C A}_{\mathbf{t}}=\boldsymbol{\alpha}+\boldsymbol{\beta} 1 \mathbf{C F O}_{\mathbf{t}}$ yang dapat dilihat pada grafik. Kualitas akrual sebelum konvergensi IFRS di Indonesia diukur dari tahun 2010 2011 sedangkan untuk kualitas akrual sesudah konvergensi penuh IFRS diukur dari tahun 20142015 yang dijelaskan oleh variabel total akrual dan arus kas operasi perusahan. Pada gambar 1 terlihat rata - rata $R$-squared hasil regresi linier sederhana terhadap model kualitas akrual antara periode sebelum dan sesudah konvergensi IFRS yang menunjukan angka relatif tinggi.

Hasil dari persistensi adalah nilai $R$-squared dari model $\mathbf{E}_{\mathbf{t}}=\boldsymbol{\beta}_{\mathbf{0}}+\boldsymbol{\beta}_{\mathbf{1}} \mathbf{E}_{\mathrm{t}-1}+\boldsymbol{\beta}_{\mathrm{t}}$ yang dapat dilihat pada grafik. Persistensi laba sebelum konvergensi IFRS di Indonesia diukur dari tahun 2010 - 2011 sedangkan untuk persistensi laba sesudah konvergensi penuh IFRS diukur dari tahun 2014-2015 yang dijelaskan oleh laba sebelum pos luar biasa pada tahun pengamatan dan laba sebelum pos luar biasa pada tahun sebelum pengamatan. Pada tabel terlihat rata - rata $R$-squared hasil regresi linier sederhana terhadap model persistensi laba antara periode sebelum dan sesudah konvergensi penuh IFRS yang tidak terlalu tinggi tetapi naik pada setiap tahun pengamatan

Hasil dari relevansi nilai adalah nilai $R$-squared dari model RET $\mathbf{t}_{\mathbf{t}}=\boldsymbol{\beta}_{\mathbf{1}}$ Earn $_{\mathbf{t}}+\mathbf{e}$ yang dapat dilihat pada grafik (gambar.2). Relevansi nilai sebelum konvergensi IFRS di Indonesia diukur dari tahun 2010 - 2011 sedangkan untuk persistensi laba sesudah konvergensi penuh IFRS diukur dari tahun 2014-2015 yang dijelaskan oleh return saham selama 15 bulan dan EPS yang dibagi dengan harga saham tahun sebelum. Pada tabel terlihat rata - rata $R$-squared hasil regresi linier sederhana terhadap model relevansi nilai antara periode sebelum dan sesudah konvergensi penuh IFRS yang yang mengalami penurunan.

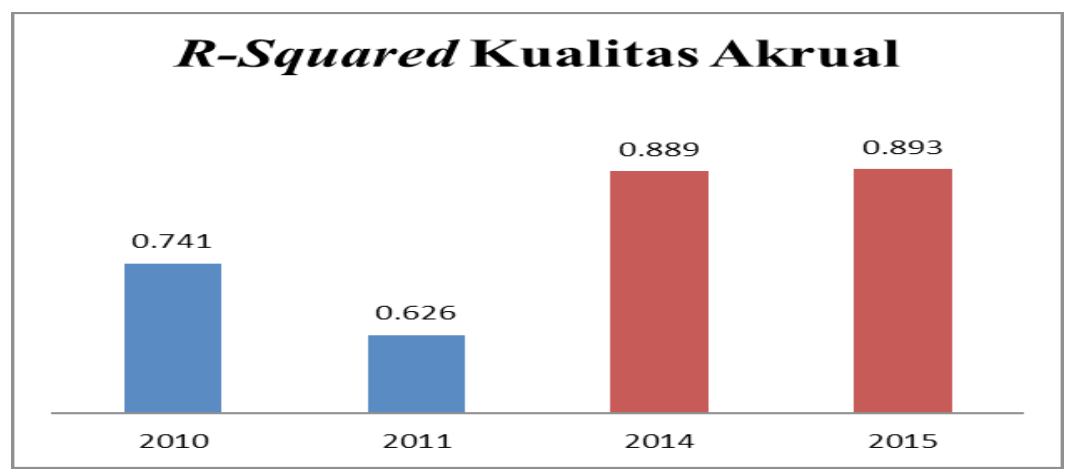

Gambar 1. R-squared Kualitas Akrual

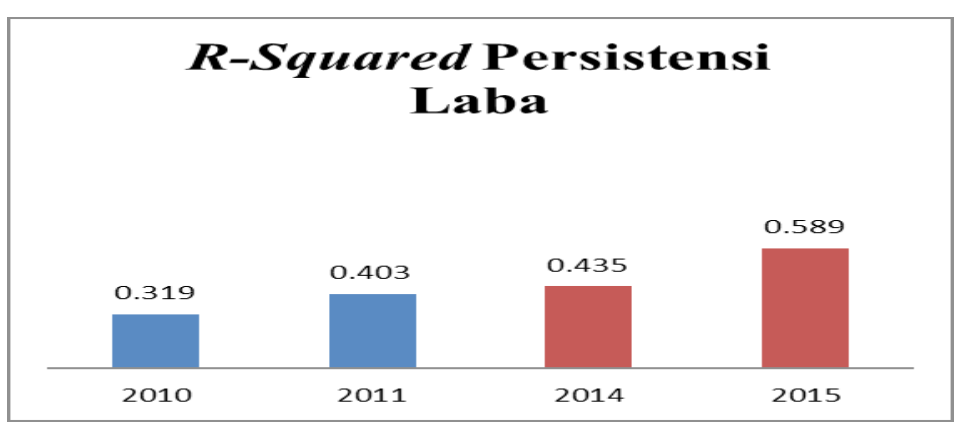

Gambar 2. R-squared Persistensi Laba 


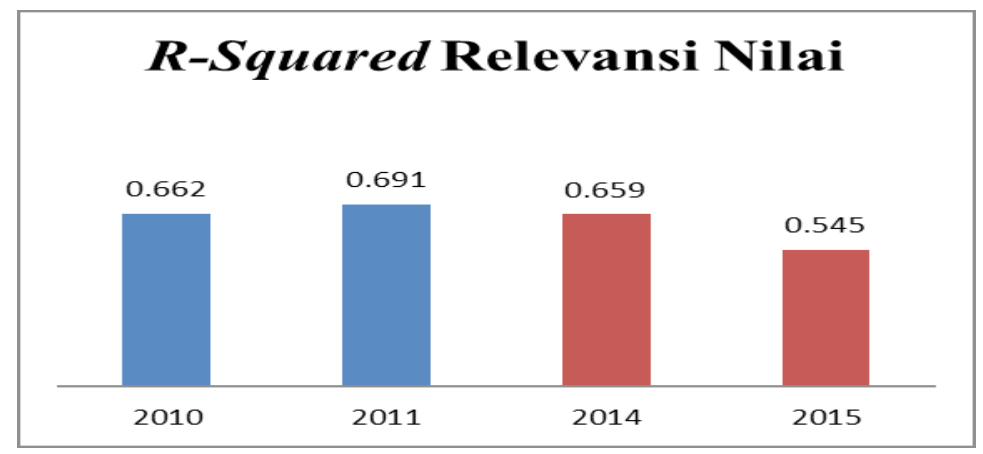

Gambar 3. R-squared Relevansi Nilai

Pada tabel 5 uji normalitas data nilai kualitas akrual sebelum konvergensi penuh IFRS memiliki nilai probabilitas signifikan sebesar 0,003 menunjukan nilai dibawah $\alpha=0,05$ artinya nilai residual kualitas akrual tidak terdistribusi secara normal. Begitu juga nilai kualitas akrual sesudah konvergensi penuh IFRS memiliki nilai probabilitas signifikan sebesar 0,000 menunjukkan nilai dibawah $\alpha=0,05$ artinya nilai residual kualitas akrual juga tidak terdistribusi secara normal. Ketika uji normalitas untuk kualitas akrual menunjukkan data yang tidak terdistribusi secara normal maka uji beda yang tepat digunakan adalah Uji Wilcoxon.

Pada tabel uji normalitas data nilai persistensi laba sebelum konvergensi penuh IFRS memiliki nilai probabilitas signifikan sebesar 0,120 menunjukan nilai diatas $\alpha=0,05$ artinya nilai residual persistensi laba terdistribusi secara normal. Begitu juga nilai persistensi laba sesudah konvergensi penuh IFRS memiliki nilai probabilitas signifikan sebesar 0,968 menunjukkan nilai diatas $\alpha=0,05$ artinya nilai residual persistensi laba juga terdistribusi secara normal. Ketika uji normalitas untuk persistensi laba menunjukkan data yang terdistribusi secara normal maka uji beda yang tepat digunakan adalah Uji Paired Test.

Pada tabel uji normalitas data nilai relevansi nilai sebelum konvergensi penuh IFRS memiliki nilai probabilitas signifikan sebesar 0,190 menunjukan nilai diatas $\alpha=0,05$ artinya nilai residual relevansi nilai terdistribusi secara normal. Begitu juga nilai relevansi nilai sesudah konvergensi penuh IFRS memiliki nilai probabilitas signifikan sebesar 0,345 menunjuk-

Tabel 5. Hasil Uji Normalitas

\begin{tabular}{llll}
\hline Model & Item & Sebelum & Sesudah \\
\hline Kualitas Akrual & Mean & 77 & 77 \\
& Std. Deviasion &, 68386 &, 89100 \\
& Sig. (2-tailed) &, 003 &, 142138 \\
& N & 77972 &, 000 \\
Persistensi Laba & Mean &, 36147 & 77 \\
& Std. Deviasion &, 233475 &, 51235 \\
& Sig. (2-tailed) &, 120 &, 236864 \\
Relevansi Nilai & N & 77 & 77 \\
& Mean &, 67681 &, 60235 \\
& Std. Deviasion &, 267668 &, 258858 \\
& Sig. (2-tailed) & 190 &, 345 \\
\hline
\end{tabular}

Sumber : Output SPSS, data diolah 
kan nilai diatas $\alpha=0,05$ artinya nilai residual relevansi nilai juga terdistribusi secara normal. Ketika uji normalitas untuk relevansi nilai menunjukkan data yang terdistribusi secara normal maka uji beda yang tepat digunakan adalah Uji Paired Test.

Rangkuman hasil pengujian hipotesis untuk melihat perbedaan sebelum dan sesudah konvergensi penuh IFRS. (tabel.6).

Berdasarkan data olah hasil uji hipotesis dapat disimpulkan sebagai berikut:

1. Variabel Kualitas Akrual, terbukti adanya perbedaan sebelum dan sesudah konvergensi IFRS yang ditunjukan oleh $R$-squared yang lebih tinggi yaitu dari nilai 0,684 menjadi 0,891 . Hal ini juga terlihat dari nilai sigfinikansi sebesar 0,000 atau lebih kecil dari $\alpha=0,05$. Dengan demikian $\mathrm{H}_{1 \mathrm{a}}$ yang menyatakan kualitas akrual pada periode sesudah konvergensi penuh IFRS lebih tinggi daripada sebelum konvergensi penuh IFRS diterima.

2. Variabel Persistensi Laba, terbukti adanya perbedaan sebelum dan sesudah konvergensi IFRS yang ditunjukan oleh $R$-squared yang lebih tinggi yaitu dari nilai 0,361 menjadi 0,512 . Hal ini juga terlihat dari nilai sigfinikansi sebesar 0,000 atau lebih kecil dari $\alpha=0,05$. Dengan demikian $\mathrm{H}_{1 \mathrm{~b}}$ yang menyatakan persistensi laba pada periode sesudah konvergensi penuh IFRS lebih tinggi daripada sebelum konvergensi penuh IFRS diterima.

3. Variabel Relevansi Nilai, ada perbedaan sebelum dan sesudah konvergensi IFRS yang ditunjukan oleh $R$-squared tetapi perbedaan adalah lebih rendah yaitu dari nilai 0,677 menjadi 0,602 . Hal ini juga terlihat dari nilai sigfinikansi sebesar 0,064 atau lebih besar dari $\alpha=0,05$. Dengan demikian $\mathrm{H}_{2}$ yang menyatakan relevansi nilai pada periode sesudah konvergensi penuh IFRS lebih tinggi daripada sebelum konvergensi penuh IFRS ditolak.

\section{Kualitas Akrual Sebelum dan Sesudah Konvergensi Penuh IFRS}

Kualitas akrual merupakan estimasi dari arus kas pada perubahan model kerja. Dengan kata lain akutansi berbasis akrual membantu memprediksi arus kas dimasa depan dengan melaporkan transaksi dan kejadian lain dengan konsesuensi kas yang diterima saat transaksi atau kejadian, bukan saat kas diterima atau dibayar. Residual dari estimasi merefleksikan akrual yang tidak berhubungan dengan realisasi arus kas dan standar deviasi dari residual tersebut merupakan kualitas akrual pada level perusahaan, dimana standar deviasi yang tinggi menunjukan kualitas akrual yang rendah.

Akrual merupakan salah satu komponen penyusun laba, selain komponen arus kas. Komponen akrual ini menjadi penting diuji kualitasnya akrena komponen ini lebih mudah dipengaruhi oleh dikresi manajemen yang oppourtunis akibat dibutuhkan banyak estimasi dan asumsi dalam penentuan jumlah komponen akrual yang harus diakui dalam laporan keuangan. Konvergensi penuh IFRS dapat membatasi ruang gerak oppotunis karena salah satu karakteristiknya yang mengharuskan peengungkapan yang lebih ekspensif.

IFRS mensyaratkan pengungkapan berbagai informasi tentang resiko baik kualitatif maupun kuantitatif, Pengungkapan dalam laporan keuangan harus sejalan dengan data atau informasi.

Tabel 6. Hasil Uji Hipotesis

\begin{tabular}{llllll}
\hline No & Variabel & Sebelum & Sesudah & Sig. & Keterangan \\
\hline 1 & Kualitas Akrual &, 684 &, 891 &, 000 & Signifikan \\
2 & Persistensi Laba &, 361 &, 512 &, 000 & Signifikan \\
3 & Relevansi Nilai &, 677 &, 602 &, 064 & Tidak Signifikan \\
\hline
\end{tabular}

Sumber : Output SPSS, data diolah 
informasi yang dipakai untuk pengambilan keputusan yang diambil oleh manajemen. Adanya tingkat pengungkapan yang makin mendekati pengungkapan penuh akan mengurangi tingkat asimetri informasi (ketidakseimbangan informasi) antara manajer dan pihak pengguna laporan keuangan. Semakin baiknya kualitas laba dari ssi kualitas akrual akan menghasilkan neraca yang secara akurat merefleksikan tingakt sumber daya yang ada bagi perusahaan untuk menghasilkan future cash flow.

Lebih luasnya pengungkapan PSAK 60 sesudah IFRS yang mengadopsi IFRS 7 disebutkan bahwa informasi terkait resiko kredit, risiko likuiditas, risiko pasar dan lainnya. Pada PSAK sebelum IFRS tidakk mengharuskan mengungkapkan informasi seperti pada PSAK sesudah IFRS. Pengungkapan yang kuat dapat membantu menarik modal dan kepercayaan investor dipasar modal.

Hasil penelitian ini sesuai dengan hasil penelitian terdahulu Firsty (2013), mengungkapkan bahwa terdapat perbedaan kualitas akrual sebelum dan sesudah penerapan konvergensi IFRS di Indonesia. Sementara hasil penelitian Beinjerink (2006) mengungkapkan tidak ada perbedaan antara persistensi laba sebelum dan sesudah penerapan IFRS.

\section{Persistensi Laba Sebelum dan Sesudah Kon- vergensi Penuh IFRS}

Laba berkualitas yang menggunakan proksi kualitas laba dikatakan laba yang terus terulang kembali dari waktu ke waktu dengan kata lain laba bersinambung dan permanen. Laba yang persisten adalah laba yang bersifat recurring sehingga dapat diandalkan untuk memprediksi kinerja perusahaan dimasa depan dan mampu mengkonfirmasi laba yang dihsailkan pada periode sebelumnya.

Adanya penggunaan nilai wajar secara luas dapat dilihat pada PSAK 50 sebelum IFRS tidak mengakui adanya komponen non trading pada saat pengungkapan awal, oleh karena itu selisih perubahan nilai wajar masuk pada kelompok ekuitas sedangkan pada PSAK sesudah selisih perubahan nilai wajar kelompok non trading masuk dalam kelompok laba rugi. Selisih nilai wajar yang diakui dalam komponen laba rugi menyebabkan pergerakan laba sehingga menyebabkan perbedaan kualitas laba sebelum dan sesudah.

Laba yang semakin persisten pada periode sesudah konvergensi IFRS menunjukkan laba yang semakin informatif. Salah satu perubahan yang akibat konvergensi IFRS adalah penekanan fair value, fair value sendiri menekankan pada penyajian nilai yang relevan dengan kondisi saat ini, seperti penilaian kembali aset-aset perusahaan dengan menggunakan bantuan appraisal. Beberapa perubahan metode akuntansi akan berdampak pada laba perusahaan antara lain, perubahan prosedur pembebanan biaya depresiasi, metode persediaan dan lain-lain. Akibatnya perubahan tersebut maka akan berdampak pada peningkatan atau penurunan laba perusahaan, dampak tersebut tentunya akan menimbulkan sejauh mana persistensi laba sesudah penerapan IFRS khususnya pada perusahaan-perusahaan manufaktur.

Hasil penelitian ini sesuai dengan hasil penelitian terdahulu Ayub (2013), mengungkapkan bahwa terdapat perbedaan persistensi laba sebelum dan sesudah penerapan konvergensi IFRS di Indonesia. Sementara hasil penelitian Meulen (2006) mengungkapkan hasil yang sama baik antara kualitas akrual sebelum dan sesudah penerapan IFRS.

\section{Relevansi Sebelum dan Sesudah Konvergensi Penuh IFRS}

Relevansi nilai merupakan kemampuan angka akuntansi untuk merangkum informasi yang mendasari harga saham sehingga relevansi nilai dindikasikan dengan sebuah hubungan statistikal antara informasi keuangan dan return saham. Relevansi nilai yang tinggi mengindikasikan hubungan yang kuat antara laba dan return pasar, semakin tinggi hubungan antara laba dan return pasar semakin berkualitas informasi yang disajikan oleh laporan keuangan tersebut.

Adanya penerapan konvergensi penuh IFRS di Indonesia diperkirakan akan memberi dampak peningkatan terhadap relevansi nilai yaitu 
kemampuan angka akuntansi untuk merangkum informasi yang mendasari harga saham. Penurunan nilai pada periode sesudah konvergensi penuh IFRS dibandingkan sebelum periode konvergeni IFRS menunjukan bahwa investor tidak banyak menggunakan informasi akuntansi dalam pengambilan keputusan. Meskipun IHSG pada periode sesudah konvergensi penuh IFRS mengalami kenaikan nampaknya informasi akutansi tidak banyak digunakan dalam penentuan harga saham. Peningkatan harga saham pada periode sesudah konvergensi IFRS lebih banyak dipengaruhi faktor lain sehingga relevansi nilai informasi akutansi justru menurun.

Di Indonesia dapat dikatakan lingkungan institusional penyusun laporan keuangan bukan standar yang menentukan kualitas akutansi dari sisi pasar, terlihat standar akuntansi disusun oleh lembaga regulasi yang dikendalikan oleh negara melalui peraturan perundang - undangan yang detail untuk mencapai keseragaman. Selain itu pendanaan perusahaan masih sangat bergantung pada perbankan sehingga pasar modal menjadi alternatif kedua.

Hasil penelitian ini sesuai dengan hasil penelitian terdahulu cahyonowati (2012), mengungkapkan bahwa tidak terdapat perbedaan relevansi nilai sebelum dan sesudah penerapan konvergensi IFRS di Indonesia. Sementara hasil penelitian Beinjerink (2008) mengungkapkan adanya perbedaan dengan adanya nilai yang lebih baik relevansi nilai sesudah penerapan IFRS dibandingkan sebelum penerapan IFRS.

\section{Simpulan, Keterbatasan Penelitian dan Saran}

Penelitian ini mencoba untuk menjawab tujuan penelitian, yaitu untuk membuktikan adanya perbedaan signifkan kualitas laba dari basis akuntansi adalah kualitas akrual dan persistensi laba sedangkan dari basis pasar adalah relevansi nilai pada perusahaan manufaktur yang terdaftar di Bursa Efek Indonesia selama periode sebelum konvergensi penuh IFRS yaitu tahun 2010 dan 2011 dengan periode sesudah konvergensi IFRS yaitu tahun 2014 dan 2015. Hasil pengujian hipotesis dengan menggunakan uji beda menunjukkan bahwa ;

1. Kualitas laba dari sisi akuntansi yaitu kualitas akrual yang dijelaskan oleh total akrual dengan arus kas operasi perusahaan manufaktur terdapat perbedaaan signifikan antara periode sebelum dengan periode sesudah konvergensi penuh IFRS. Perbedaan yang signifikan ini menjadikan kualitas laba lebih baik dilihat dari lebih tingginya nilai pada periode sesudah konvergensi penuh IFRS dibandingkan pada periode sebelum konvergensi penuh IFRS. Hal ini terlihat disebabkan adanya pengungkapan yang lebih ekspensif pada periode sesudah konvergensi penuh IFRS sehingga mengurangi tingkat asimetri informasi.

2. Kualitas laba dari sisi akuntansi yaitu persistensi laba yang dijelaskan oleh laba sebelum pos luar biasa pada periode $\mathrm{t}$ dengan periode $\mathrm{t}-1$ perusahaan manufaktur terdapat perbedaaan signifikan antara periode sebelum dengan periode sesudah konvergensi penuh IFRS. Perbedaan yang signifikan ini menjadikan kualitas laba lebih baik dilihat dari lebih tingginya nilai pada periode sesudah konvergensi penuh IFRS dibandingkan pada periode sebelum konvergensi penuh IFRS. Hal ini disebabkan adanya penekanan penggunaan fair value sehingga mempengaruhi metode yang berdampak pada nilai laba.

3. Kualitas laba dari sisi pasar yaitu relevansi nilai yang dijelaskan oleh return saham dengan earning per share perusahaan manufaktur tidak terdapat perbedaaan signifikan antara periode sebelum dengan periode sesudah konvergensi penuh IFRS. Nilai relevansi nilai yang lebih rendah pada periode sesudah dibandingkan periode sebelum konvergensi penuh IFRS menunjukan tidak adanya peningkatan kualitas laba. Hal ini disebabkan bahwa investor tidak banyak menggunakan informasi akuntansi dalam pengambilan keputusan investasi, selain itu selain itu pendanaan perusahaan masih sangat 
bergantung pada perbankan yang menjadikan pasar moda alternatif kedua sehingga harga saham lebih banyak dipengaruhi faktor lain.

Penelitian ini mempunyai keterbatasan, terutama dalam hal ;penggunaan empat atribut kualitas laba yaitu kualitas akrual dan persistensi dari sisi akuntansi dan relevansi nilai dari sisi pasar. Penelitian ini terbatas hanya pada industri manufakturyang terdaftar di Bursa Efek Indonesia sehingga masih banyak perusahaan emiten lainnya yang belum masuk dalam penelitian ini. Penelitian ini hanya mencakup periodes penelitian selama 4 tahun yaitu tahun 2010 - 2011 untuk periode sebelum konvergensi penuh dan tahun 2014 - 2015 untuk periode sesudah konvergensi penuh IFRS sehingga penelitian masih dalam waktu terbatsa dan belum bisa digeneralisir untuk periode yang lebih panjang.

Pada penelitian yang akan datang terdapat beberapa hal yang perlu diperhatikan, diantaranya adalah sebagai berikut ;

1. Dalam penelitian mendatang diharapkan melakukan penelitian kualitas laba dengan melibatkan faktor lain seperti prediktabilitas , smoothness dari sisi akutansi dan relevansi nilai dari sisi pasar dengan menggunakan metode lain.

2. Dalam penelitian mendatang diharapkan melakukan penelitian kualitas laba pada emiten selain manufaktur.

3. Dalam penelitian mendatang diharapkan melakukan penelitian kualitas laba dengan menambah rentang waktu penelitian.

4. Bagi investoryang akanmengambilkeputusan lebih melihat sisi akuntansi dibandingkan sisi pasar.

5. Bagi regulator dapat terus menyesuaikan standar akuntansi agar manfaat yang akan dicapai.

\section{Daftar Rujukan}

Alali, F.A. \& Foote, P.S. (2012). The Value Relevance Of International Financial Reporting Standards: Empirical Evidence in an Emerging Market. The International Journal of Accounting, 47, 85-108.
Aristiya, Maria Maya. 2013. Analisis Perbedaan Tingkat Konservatisme Alutansi Laporan Keuangan Sebelum dan Sesudah Konvergensi IFRS.

Ball, R.,A. Robin, and J. S. Wu. (2003). "Incentives versus standards: Properties of accounting income in four East Asian countries." Journal of Accounting \& Economics

Barth, M. E., Landsman, W. R. \& Lang, M. (2008). International Accounting Standards and Accounting Quality. Journal of Accounting Research, 46, 467-498.

Bartov, E., Goldberg, S. \& Kim, M. (2005). Comparative Value Relevance Among German, U.S. and International Accounting Standards: A German Stock Market Perspective. Journal of Accounting, Auditing and Finance, 20, 95-119.

Basu, S. (1997). The conservatism principle and the asymmetric timeliness of earnings. Journal of Accounting and Economics 24, 3-37.

Beijerink, M. 2008. Information Quality beetween IFRS and US GAAP. Enschede: Universiteit Twente.

Belkaoui, Ahmed Riahi. 2004. Teori Akuntansi, Edisi Revisi. Salemba Empat, Jakarta.

Cahyonowati, Nur dan Ratmono Dwi. 2012. Adopsi IFRS dan Relevansi Nilai Informasi. Jurnal Akuntansi dan Keuangan Vol. 14 No. 2 hal. 105-115.

Clauya, Ursula \& Budiharta P. 2014. Analisis Pebedaan Kualitas Akuntansi Sebelum dan Sesudah Konvergensi IFRS. Fakultas Ekonomi Unversitas Atma Jaya Yogyakarta

Daske, H., Hail, L., Leuz, C. \& Verdi, R. (2008). Mandatory IFRS Reporting Around The World: Early Evidence on The Economic Consequences. Journal of Accounting Research, 46, 1085-1142.

Dechow, \& Dichev. 2002. The Quality of Accruals and Earnings: The Role of Accrual Estimation Errors. The Accounting Review, 35 -39.

Djamaluddin, Subekti, Handayani Tri Wijayanti dan Rahmawati, 2008. Analisis Pengaruh Perbedaan Antara Laba Akuntansi dan Laba Fiskal Terhadap Persistensi Laba, Akrual dan 
Arus Kas Pada Perusahaan Perbankan Yang Terdaftar Di Bursa Efek Jakarta. Jurnal Riset Akutansi Indonesia Vol 11 No.1

Doupnik, T., Hector Perera. (2007). International Accounting, Mc Graw Hill Book, New York.

Famila, M Ayub. 2013. Perbandingan Kualitas Laba Antara Periode Sebelum dan Sesudah Pengadopsian IFRS di Indonesia. Faklutas Ekonomi Universitas Indonesia.

Francis, J., LaFond, R., Olsson, P. M., 2004. Cost Of Equity and Earning Atributes. The Accounting Review, 267 - 1010

Gamayuni R. 2009. Perkembangan Standar Akuntansi Indonesia Menuju International Financial Reporting Standard. Jurnal Akuntansi Keuangan ISSN 1410-1831

Godfrey, Hodgson, Tarca. 2009. Accounting Theory: 7 Edition. Wiley

Hung, M. \& Subramanyam, K.R. (2007). Financial Statement Effects of Adopting International Accounting Standards, The Case of Germany. Review of Accounting Standards, 12, 623-657.

Karampinis, N. \& Hevas, D. (2011). Mandating IFRS in an Unfavorable Environment: The Greek Experience. The International Journal of Accounting, 46, 304-332

Kieso, Donald E., Jerry J Weygant., dan Terry D Warfield., 2009. Intermadiate Accounting. 13th Edition. Wiley International Edition.

Kusumo,Yuro Bimo \& Subekti, Imam. 2013. Relevansi Nilai Informasi Akuntansi Sebelum Adopsi IFRS dan Setelah Adopsi IFRS pada Perusahaan yang Tercatat dalam Bursa Efek Indonesia. Fakultas Ekonomi Universitas Brawijaya.

Lipe, R., 1990. The Relation Between Stock Return and Accounting Earnings Given Alternative Information. The Accounting Review 65: 49-71.

Liu, J., \& Liu, C. (2007). Value Relevance Of Accounting Information In Different Stock Market Segments: The Case of Chinese A-, Band H-shares. Journal of International Accounting Research, 6, 55-81.

Martani Dwi, 2001. Dampak Implementasi IFRS Bagi Perusahaan. Jurnal Akuntansi Keuangan
ISSN 2088-8317 / No. 48 Tahun V Juli 2011, hal. 98-99

Meulen. V.D., S., Gaeremynck, A., \& Willekens, M. 2007. Attribute Differences Between US GAAP and IFRS Earnings: An exploratory study. The International Journal of Accounting, 42(2), 123-142.

P.H Yusvika, 2014. Analisis Perbedaaan Manajemen Laba Sebelum dan Sesudah Penerapan Standar Akuntansi Keuangan ( Konvergensi IFRS). Fakultas Ekonomi Universitas Negeri Padang.

Penman, S. H \& Zhang, X-J. 2002. Accounting Corservatism, The Quality of Earnings and Stock Returns, The Accounting Review, 237 -264 .

Prastika, Nurhikmah Esti, dkk. 2013. Analisis Komparasi Terhadap Kualitas Akuntansi Sebelum dan Sesudah Penerapan Standar Akuntansi Keuangan International di Indonesia.

Putri, Kurnia Putri, 2013. Menguji Perubahan Kualitas Akrual dan Relevansi Nilai Laporan Keuangan Sebelum dan Sesudah Full Adopis IFRS. Fakultas Ekonomi Universitas Negri Surabaya.

Schipper, K. (1989). Commentary on earnings managements. Accounting Horizons

Sianipar, Glory Augusta E. M. Dan Marsono.2013.Analisis Komparasi Kualitas Informasi Akuntansi Sebelum dan Sesudah Pengadopsian Penuh IFRS di Indonesia. Diponegoro Journal of Accounting, Vol.2 No.3 Hal 1

Suwardjono. 2005. Teori Akuntansi: Perekayasaan Pelaporan Keuangan, Edisi Ketiga, Yogyakarta: BPFE.

Tucker, J.W. and P.A. Zarowin, 2006, "Does IncomeSmoothing ImproveEarnings Informativeness?", The Accounting Review, Vol. 81, No. 1, January: 251-270.

Watts, R. L, Jerold L. Zimmerman. (1986). Positive Accounting Theory. New Jersey Pretince Hall

Watts, R.L. (2003a). Conservatism in accounting part I: explanations and implications. Accounting Horizons 17, 207-221. 
Watts, R.L. (2003b). Conservatism in accounting part 2: Evidence and research opportunities. Accounting Horizons (December): 287-301, The Accounting Review 77 (2): 237-264

Wolk, H., M. Tearney, and J. Dodd. (2000). Accounting Theory: A Conceptual and Institutional Approach, Third Edition. SouthWestern College Publishing. 